Article

\title{
Refugee Organizations' Public Communication: Conceptualizing and Exploring New Avenues for an Underdeveloped Research Subject
}

\author{
David Ongenaert \\ Department of Communication Sciences, Ghent University, 9000 Ghent, Belgium; E-Mail: david.ongenaert@ugent.be
}

Submitted: 31 December 2018 | Accepted: 25 March 2019 | Published: 28 June 2019

\begin{abstract}
The world has faced a major increase in forced displacement and the theme has also become the subject of many public, media and political debates. The public communication of refugee organizations thereby increasingly impacts their operations, the public perception on forcibly displaced people and societal and policy beliefs and actions. However, little research has been conducted on the topic. Therefore, this conceptual article aims to (1) define refugee organizations' public communication, (2) situate it within broader research fields, and (3) motivate the latter's relevance as research perspectives. In order to be able to achieve these research objectives, the article first discusses the social and scientific relevance of the research subject and identifies important gaps within literature which both form an essential scientific base for developing the main arguments. Adopting a historical perspective, the article demonstrates that in recent decades the social and scientific relevance of research on strategic and non-profit communication in general and on refugee organizations' public communication in particular have increased. Nevertheless, these fields remain underdeveloped and are mostly text-focused, while the production and reception dimensions are barely explored. Remarkably, however, little or no research has been conducted from an organizational communication perspective, although this article demonstrates that the subject can be adequately embedded in and examined from the fields of strategic, non-profit and public communication. Finally, the article highlights the relevance of the holistic Communicative Constitution of Organizations perspective and argues that future research can benefit by adopting multi-perspective, practice-oriented, multi-methodological, comparative and/or interdisciplinary approaches.
\end{abstract}

\section{Keywords}

Communicative Constitution of Organizations; displacement crises; mediated humanitarianism; non-profit communication; public communication; refugee organizations; strategic communication

Issue

This article is part of the issue "Refugee Crises Disclosed: Intersections between Media, Communication and Forced Migration Processes", edited Vasiliki Tsagkroni (Leiden University, The Netherlands) and Amanda Alencar (Erasmus University Rotterdam, The Netherlands).

(C) 2019 by the author; licensee Cogitatio (Lisbon, Portugal). This article is licensed under a Creative Commons Attribution 4.0 International License (CC BY).

\section{Introduction}

Although so-called 'refugee crises' have always occurred throughout history, forced migration has increased significantly recently: from $\mathbf{4 2 . 7}$ million forcibly displaced people (FDPs) worldwide in 2007 to 68.5 million in 2017. The largest growth took place between 2012 and 2015, and was largely driven by conflicts in Syria, Iraq, Yemen, and Sub-Saharan Africa (the Office of the United Nations High Commissioner for Refugees [UNHCR], 2018). Since the summer of 2015, the theme of forced migration has also been ubiquitous in (often polarized, overlapping and interacting) public, media and political debates (Hellman \& Lerkkanen, 2019).

Within such contexts, refugee organizations often play key roles. More concretely, they provide aid, assistance and/or protection to FDPs (Betts, Loescher, \& Milner, 2012), but also try to inform, raise awareness and set the agenda through public communication (e.g., press releases, news stories, photos, videos, interviews, 
etc.). Therefore, they provide diverse communication content to news media and increasingly communicate directly with citizens via social media and websites (Atkin \& Rice, 2013). Although these organizations significantly impact how the public perceives FDPs (Chouliaraki, 2012) and as such can have broader policy and societal consequences, few studies have examined how they attempt to influence public, media and political agendas. Therefore, this conceptual article first reflects on the social and scientific relevance of refugee organizations' public communication and provides a brief overview of existing research by adopting McQuail's (2010) frequently used division of the mass communication process into text, production and reception dimensions. Based on and responding to the identified tendencies, and gaps within literature, the third section defines and situates the barely theorized notion of refugee organizations' public communication within various fields of organizational communication research, and motivates their relevance to examine the research subject. This is illustrated by a discussion of the highly relevant Communicative Constitution of Organizations (CCO) perspective. The final section reflects on challenges and new directions for future studies. As such, the article aims to set out lines for further research.

While refugee organizations' public communication is discussed, we first briefly elucidate our notion of the barely theorized concepts of 'refugee organization' and 'forcibly displaced person (FDP)'. Based on the broad statute of key organization UNHCR (2010) and practical knowledge, we consider refugee organizations as a type of humanitarian organization whose main aim is to provide protection, assistance and/or aid to refugees, asylum-seekers, internally displaced people, stateless people and/or other people in similar situations. We opt for this rather broad definition in order not to exclude, nor ignore the diversity within the working field of refugee organizations (Walker \& Maxwell, 2009). Further, this article uses -if appropriate and feasible, and instead of the commonly used but rather narrow, essentializing and legal term 'refugee' (Harrell-Bond \& Voutira, 1992), the more comprehensive, humane and correct umbrella term 'FDP'.

\section{Social and Scientific Relevance}

Adopting a historical perspective, we observe that the relevance, opportunities and limits of refugee organizations' public communication shape and are shaped by various societal trends. We first overview various challenging social tendencies in diverse interacting institutional fields, and then discuss the evolving vital relationship between humanitarianism and journalism.

\subsection{Challenging Social Trends}

First, as outlined above, the problem of forced migration has expanded considerably recently and, despite many solidarity initiatives, the humanitarian needs are considerable (UNHCR, 2017). However, although there are significant national and socio-demographic differences (age, education, level of urbanization, size and nature of migration, etc.), recent public opinions in Europe about refugees and immigrants seem to be often rather negative and/or more negative than before (European Commission, 2018; Lucassen, 2018). Refugees are often regarded as threats to host countries' welfare, social cohesion, culture, public health and security, and frequently confronted with xenophobia and the populist right's increasing popularity (Frelick, 2007), regularly leading to negative psychosocial consequences (Leudar, Hayes, Nekvapil, \& Turner Baker, 2008). However, during the Cold War and in the 1990s refugees were often regarded respectively as freedom advocates and victims of human rights violations and wars (Frelick, 2007).

Lucassen (2018) explains this recently increased social dissatisfaction with (forced) migration by referring to some necessary and sufficient historical conditions which recently merged together: growing discomfort with the immigration and integration of former colonial and labour migrants, Islam, Islamist terrorism and globalization, and a rise of social inequality and right populism. However, the negative public opinions can also be partly explained by the influence and representations of news media. The majority of European citizens sometimes interact with immigrants and refugees-again, with national and socio-demographic variations (European Commission, 2018). However, many still have limited interpersonal contact and base their opinions strongly on news coverage (Boomgaarden \& Vliegenthart, 2009), mostly the main information source on distant suffering (Waters \& Tindall, 2011). News media, however, nowadays often produce conflict and human-interest stories, focusing on immigrants rather than immigration (Benson, 2013). While recognizing differences between news media, FDPs are frequently stereotyped, collectivized, decontextualized, given no voice and/or represented as inherently ambivalent: they are simultaneously both a 'victim' of a conflict and a 'danger' for the (inter)national order (Chouliaraki \& Zaborowski, 2017). Apart from ethics, media representations can have broader societal and policy consequences:

How we label, categorize and, in turn, differentiate between those on the move...has enormous implications on the kind of legal and moral obligations receiving states and societies feel towards them. This is perhaps even more salient nowadays in the context of the process of reform of the global governance of migration initiated with the 2016 New York Declaration for Refugees and Migrants. (Sigona, 2018, p. 456)

Considering the policy level, states have the main legal responsibilities concerning (forced) migration and generally provide asylum and/or other forms of aid and/or assistance. However, in recent decades, various states- 
both in the Global North and South, and often electorally driven-have introduced more restrictive asylum legislation, policies and practices and have become more reluctant to cooperate with refugee organizations (Betts et al., 2012). For instance, many border and migration management policies of the European Union and of other states are based on the humanitarian-security nexus. Joint military-policing-humanitarian efforts thereby blur the lines between the involved military, police and humanitarian institutions and operations (Andersson, 2018). This "uneasy alliance" (Walters, 2011, p. 145), characterized by interagency tensions and sharing practices, often "mixes reception and rejection, care and coercion, in complex ways that reinforce the official border security model-a trend that is also (if not equally) in evidence at other borders across the globe" (Andersson, 2017, p. 66).

Many states and bodies legitimize these policies and practices by using security-humanitarian discourses, which reproduce the perceived ambivalent character of FDPs (supra) and war, emergency and rescue imaginaries (Andersson, 2018; Musarò, 2017). Within these imaginaries "the bio-political imperative of managing lives is...expressed through an aesthetic of trauma, where 'war' (on migrants) is represented both as an intimate experience of sorrow and as a public act of peacemaking" (Musarò, 2017, p. 11). This humanitarian-security nexus is enabled by the increasing globalization, and interdependence and interactions between various refugee related regimes that shape states' refugee policies, and also influences refugee organizations' public communication (infra).

Drawing on the above-mentioned observations, it is essential for refugee organizations' operations to create effective public communication strategies (Dijkzeul \& Moke, 2005), especially because "humanitarian appeals have the potential to mitigate opposition to immigration, even in the presence of countervailing threats" (Newman, Hartman, Lown, \& Feldman, 2015, p. 604). Therefore, refugee organizations promote certain narratives about issues and their causes and solutions (Entman, 1993) and by bringing into being "situations, objects of knowledge, and the social identities of and relations between people and groups of people" (Fairclough \& Wodak, 1997, p. 258) they attempt to set media, public and political agendas and construct a social reality. Although being far from simple, at the same time critical junctures, such as the current Syrian crisis, can also provide opportunities. More concretely, it could be appropriate periods to influence governmental policies and especially to reassess the own communication policies and practices (Green, 2018). Generally, however, (international) non-governmental organizations review their own communication less than organizations from other sectors. This is largely due to the cost and the (methodological) complexity of campaigns and evaluations (O'Neil, 2013), and forms an additional reason for academics to investigate refugee organizations' public communication strategies.

\subsection{Evolving Relationship with Journalism}

Since the 1980s, the number of organizations in the humanitarian landscape has increased significantly. This has led to a fierce competition for donations from governments, businesses and citizens and a subsequent struggle for media attention (Cottle \& Nolan, 2007), especially because the scale of the provided aid does not necessarily correspond with the scale of the humanitarian crisis, but rather with the degree of media interest (Franks, 2013). In that regard, the perceived newsworthiness of public communication by journalists would increase depending on the conformity to media conventions (Carragee \& Roefs, 2004). This 'media logic' refers to (mainstream) news media's news values, formats, organization, working conditions, norms and values (Altheide, 2004; Altheide \& Snow, 1979). However, it often results in simplification, polarization, intensification, concretization, personification and stereotyping. Furthermore, individuals and organizations within the public sphere have varying degrees of resources (e.g., funding, knowhow and experience, social relationships, reputation, etc.), which can be valued differently depending on the specific context (Ihlen, 2007). In that regard, public communication generally strengthens the authority of political institutions and multinationals (Wolfsfeld, 2011).

However, given the evolving news ecology and emergence of a global public sphere, refugee organizations and particularly (international) NGOs obtain greater agenda-setting possibilities (Castells, 2008; Van Leuven, Deprez, \& Raeymaeckers, 2013). Due to trends of digitalization, cost savings and the associated higher workload (Schudson, 2011), journalists use more pre-packaged information (Reich, 2010), and NGOs' public communication, often largely conforming with mainstream media conventions, has been professionalized (Waisbord, 2011). Furthermore, journalists are often more responsive to information subsidies offered by NGOs than by governments, politicians or firms (Reich, 2011). Hence, NGOs provide diverse content to obtain greater news access and coverage (Castells, 2008) wherein mostly international NGOs succeed (Van Leuven \& Joye, 2014).

Regarding academic research, many scholars have studied the agenda-setting efforts of humanitarian organizations in general (Ongenaert \& Joye, 2016; Van Leuven \& Joye, 2014). Less have done so for refugee organizations (Dimitrov, 2006, 2009). Second, most studies examine first-level or traditional agenda-setting, which want to tell news consumers 'what to think about' (Sallot \& Johnson, 2006, p. 152, original italics; McCombs, 2014; McCombs \& Shaw, 1972). Traditional agenda-setting is concerned with gaining attention for a certain topic. After obtaining news media access, however, public communication continues to influence the media agenda and public opinion in terms of 'what to think'. This is second-level or attribute agenda-setting and it is concerned with how we should understand a topic and on 
which attributes of the topic we consequently should focus (Sallot \& Johnson, 2006, p. 152, original italics). As the state of the art will reveal, only few studies have thoroughly examined the discursive strategies deployed by refugee organizations in the context of secondlevel agenda-setting (e.g., Chouliaraki, 2012; Ongenaert \& Joye, 2019), and almost none have investigated their production and reception contexts. These shortcomings are remarkable as refugee organizations' public communication contributes significantly to the public perception of FDPs and displacement crises (Chouliaraki, 2012), and thus can have broader policy and societal consequences (supra). Drawing on the above-mentioned observations, refugee organizations' public communication strategies deserve a more in-depth, multidimensional academic exploration.

\section{State of the Art}

Given the limited and fragmented research on the production and reception dimensions, we refer, if relevant and possible, to studies on the humanitarian sector and humanitarian communication in general. While many studies on these dimensions often generalize findings to the entire humanitarian sector-mostly in a theoretically sound way, future research should empirically validate these claims for specific types of humanitarian organizations, including refugee organizations.

In line with Orgad's (2018) review of research on humanitarian communication in general, two similar main approaches can be distinguished in research about the subject. The first and most common approach, 'the ethical promise of representation', is text-focused and "examines whether they deliver on their promise to advance understanding and elicit care and responsibility for others in need beyond borders" (Orgad, 2018, p. 68). The second and far less used approach, "humanitarian communication as a practice, in practice', investigates refugee organizations' public communication as socially situated practices: "the production of communication within the changing conditions of NGO operations and the media environment, and its reception by certain audiences at certain places and times" (Orgad, 2018, p. 72, original italics).

Within the first approach, several studies investigate refugee organizations' public communication output, and do so from diverse (often interdisciplinary) perspectives and disciplines within social sciences and humanities, including communication sciences, sociology, history, linguistics, (social) anthropology, (international) political sciences and international relations and diplomacy. Discursive strategies that primarily target citizens can be distinguished from those that are mainly directed at governments. Within the first subfield, most research investigates the representation of FDPs, in terms of discursive strategies (e.g., the extent of personalization, individualization, etc.), represented characteristics (e.g., agency, capacities, roles, attitudes, norms and values, etc.) (e.g., Bettini, 2013; Rodriguez, 2016) and sociodemographic categories, 'voiced' people, types of disseminated messages and ethical implications (e.g., HarrellBond \& Voutira, 2007; Malkki, 1996; Pupavac, 2008; Rajaram, 2002; Vasavada, 2016). Few academics, however, investigate the broader regimes of representations and underlying normative concepts that structure these representations and are used as moral justification for solidarity with FDPs (e.g., Chouliaraki, 2012). Nevertheless, research on this subject is particularly relevant to deconstruct refugee organizations' public communication and examine if and to which extent it reproduces and reflects broader societal discourses.

Within the second subfield of strategies mainly directed at states, 'cross-issue persuasion' is very relevant (Betts, 2010). This communication strategy implies that refugee organizations attempt to persuade states to engage in solidarity by relating refugee protection, assistance and/or aid to western countries' self-perceived larger security, economic, humanitarian and/or development interests, but as such represent FDPs as mere objects of negotiations (e.g., on resettlement, refugee protection, etc.). This political realist argumentation strategy is, just as the humanitarian-security nexus (supra), enabled by and a strategic response to the increasing globalization, and interdependence and interactions between various refugee related regimes. For instance, UNHCR nowadays often argues that irregular migration to western states can be limited by supporting refugee protection in the Global South, partially responding to the western security agenda (Betts, 2009, 2010). However, while thus relevant, this communication strategy is rarely examined.

Considering production practices, various authors have investigated trends within the political economy of the humanitarian sector in general and humanitarian communication in particular. This involves attention for the increasing number of organizations in the humanitarian landscape and their growing size, the subsequent rising competition for donations, aid and media attention, and the development of new media and marketing strategies to adapt to these trends, including the use of branding, commodification and celebrities (Cottle \& Nolan, 2007; Franks, 2013). However, few studies scrutinize, especially in the context of refugee organizations, the shaping role of organizational characteristics, such as core values and principles, funding structure and relationships with states (Dijkzeul \& Moke, 2005), the challenges to meet the media logic (Ongenaert \& Joye, 2019) or communication practices as reflections of larger technological, political, economic and/or sociocultural shifts in society (Nikunen, 2016).

Regarding audience receptions, several authors have investigated various audience related challenges for the humanitarian sector in general. Besides negative public opinions (supra), these include fragmentation and individualization of and a diversity of interpretations among audiences, compassion fatigue (Höijer, 2004; 
Tester, 2001), states of denial (Cohen, 2001), and a growing cynicism towards and aversion of institutional aid campaigns (Chouliaraki, 2012). However, to our knowledge, little research exists on the perception of refugee organizations' public communication. Likewise, while already various studies have been conducted on factors that increase audiences' responsiveness to humanitarian communications (for an overview, see Seu \& Orgad, 2017), specific research in the context of refugee organizations' public communication or on engagement with public attitudes towards FDPs is very limited (e.g., Dempster \& Hargrave, 2017).

We can conclude that a significant body of work examines the text dimension, often with normative focuses on representations, but largely ignoring organizational perspectives. However, in order to explain these communication strategies, it is important to examine the underlying production and reception contexts. As Orgad (2018, pp. 75-76) argues: "[f]or scholarship potentially to inform and influence humanitarian communication practice, it is crucial that it is grounded in an understanding of the economic, material, organizational and political conditions of NGOs' work." Therefore, the next section discusses various relevant fields that can provide complementary, holistic perspectives, and sets out lines for further research that bridges normative and organizational perspectives.

\section{Situating Refugee Organizations' Public Communication}

Responding to the observed gaps in literature, we identified various relevant and (partially) overlapping fields from which the barely theorized notion of 'public communication' of refugee organizations' (called here as such for reasons of clarity, specificity and simplicity) can be approached and defined. This concerns the fields of strategic, non-profit and public communication, which will be discussed in the following subsections. This article does not claim that these are the only or even most relevant fields from which the subject can be approached or defined. It can be argued, for example, that humanitarian communication would be a more specific and relevant starting point. However, as Orgad's (2018, p. 76) remarks:

Every NGO has idiosyncratic characteristics, related to its orientation (e.g., emergency- or developmentfocused), size, history, practices, work culture, specific individuals, finances, and so on. Making generalizations or applying findings from one NGO at a particular time to humanitarian communication in general, may be difficult if not impossible.

In addition to and considering their specific orientations and operations, refugee organizations differ from (the more examined) generalist humanitarian and/or development NGOs, and cannot be situated within one of these two categories. Therefore, we opt to discuss broader but relevant fields which (1) provide enough conceptual space to fully comprise and define our subject which can be situated in their intersection; (2) from which the subject-remarkably-has not been examined yet; but (3) which can function as the basis for an innovative and conceptually sound theoretical framework.

\subsection{Strategic Communication}

We first briefly overview the research field of strategic communication, and then outline its relevance to examine the research subject, also by specifically discussing the CCO perspective.

\subsubsection{Defining Strategic Communication}

Strategic communication as a practice is increasingly being used as an umbrella term for various goal oriented communication activities that are being investigated within the fields of public relations, marketing communication, organizational communication, public diplomacy, etcetera (Holtzhausen \& Zerfass, 2015). Strategic communication, however, is also a research field that transcends and integrates (or at least is assumed to do so) the just-mentioned (formerly separated and often isolated) research domains into an interdisciplinary, unifying framework from which communication processes can be examined and new, complementary insights can be provided (Falkheimer \& Heide, 2018).

Within this research field, two main approaches can be distinguished. Within the dominant organizationalcentric approach, strategic communication can be defined as "the purposeful use of communication by an organization to fulfil its mission" (Hallahan, Holtzhausen, Van Ruler, Verčič, \& Sriramesh, 2007, p. 3). This approach examines strategic communication's importance for organizational efficiency, management, etc. Frequently addressed subjects-which are often overlooked within research on refugee organizations' public communication, are communication management, planning, audience segmentation, message design, relationship building, campaigns, and evaluation (Heide, Simonsson, von Platen, \& Falkheimer, 2017). However, since the beginning of the 20th century, a more socially oriented approach has emerged in which strategic communication is analyzed in relation to citizens' attitudes and/or behaviour, public opinion, democracy, culture, etc. Building on the idea that both approaches and the abovementioned research fields should be combined in a more holistic perspective, Holtzhausen and Zerfass (2013, p. 74) extended Hallahan et al.'s (2007) definition. They consider strategic communication as "the practice of deliberate and purposive communication that a communication agent enacts in the public sphere on behalf of a communicative entity to reach set goals". However, as Oliveira (2017, p. 57) remarks: 
Although the pillars of the alternative paradigm are described by Holtzhausen and Zerfass as the communication at micro, meso and macro level, by focusing on the public sphere dimension, some areas, like organizational communication and the CCO principle, are excluded (2013, p. 76). [R]esearch would be more fruitful with a cross-fertilization of the three paradigms, meaning that theories, concepts and research focuses could be synthesized in a broader approach...rather than driving an exclusive definition, even if the roots are recognized.

In the section on non-profit communication we discuss Oliveira's (2017) definition.

\subsubsection{Relevance of Strategic Communication}

Strategic communication's relevance as a framework to examine organizations' communication can be explained by various factors (Hallahan et al., 2007, p. 10), whereby many aspects of refugee organizations' practices and working field are reflected. First, within the 21st century postmodern global society, previously clearly distinguishable types of communication activities and genres (e.g., advertising, product placement, sponsoring) and fields (e.g., public relations, advertising, marketing, etc.) have converged, driven by new (digital) media technologies and economies. Furthermore, people's impressions about organizations are always influenced by previous impressions and experiences. Therefore, it is important to study organizations' communication from a strategic and integrative perspective (Hallahan et al., 2007).

Furthermore, while most studies underwrite a 'beingrealism' ontology, and the traditional positivist managerial perspective is still dominant in the field of strategic communication, Falkheimer and Heide (2018) also identify a reflexive turn that investigate the active, subjective role of researchers during research. Additionally, Mumby (2014) identifies an interpretative and linguistic turn, which has led to a shifting (more interdisciplinary) research focus towards themes such as organizations' discourses, narratives and power. These academic turns seem to provide a relevant scientific base for reflexive, critical research on strategic communication in general and on refugee organizations' public communication in particular, which is necessary to facilitate theoretical and methodological pluralism within the field (Heide, von Platen, Simonsson, \& Falkheimer, 2018).

\subsubsection{The CCO Perspective as a New Avenue}

Common within the above-mentioned turns is that communication is no longer seen as an ancillary function of organizations, but as a fundamental building block and signifier (Mumby, 2014). In that regard, it seems relevant to adopt the CCO perspective (more widely) in research on strategic communication and on refugee organizations' public communication in particular. It is im- portant to mention that the CCO perspective, with origins in the subfield of organizational communication, is not a delineated theory. As Putnam and Nicotera (2010, p. 158) state:

CCO is first and foremost a collection of perspectives about grounding the role of communication in the ontology of an organization. Thus, CCO is a body of work connected by a central question or an overall problem rather than a clear-cut answer.

More concretely, the CCO perspective argues that communication is not just an activity that occurs within or between organizations, but forms the constitutive process of organization. 'Organization' thereby both refers to a process or perpetual state of change, an object or entity, and an entity grounded in action-as organizations are not objective, constant, stable entities but are (re)produced by communication, and these outcomes and processes reflexively shape communication (Putnam \& Nicotera, 2010). Heide et al. (2018, p. 456, original italics) remark:

The CCO perspective makes it clear that communication cannot be reduced to a single profession or organizational function (irrespective of whether corporate communication, public relations or marketing is used), because communication is a process that cuts across the entire organization and is constitutive of its very existence (Kuhn \& Schoeneborn, 2015). Regarded this way, communication is not a variable. Rather we understand communication as a perspective or lens that can help researchers to understand organizational processes and actions.

Cooren, Kuhn, Cornelissen and Clark (2011, pp. 1151$1154)$ identified six premises that are shared by most CCO schools of thought. While the latter three premises are also relevant, the first three premises seem to explicitly respond to gaps and limitations of research on refugee organizations' public communication, and could guide future studies. We briefly discuss their relevance. First:

CCO scholarship studies communicational events. If the CCO perspective is to be taken seriously, it means that one should not only pay attention to language and discourse, but also to the interactional events that constitute the building blocks of organizational reality...[a]ny turn of talk, discourse, artifact, metaphor, architectural element, body, text or narrative should...be considered...[i]t means that one should examine what happens in and through communication to constitute, (re-)produce, or alter organizational forms and practices, whether these are policies, strategies, operations, values, (formal or informal) relations, or structures. (Cooren et al., 2011, original italics, p. 1151) 
This premise emphasizes the importance of examining holistically the text dimension, as this will inform our understanding about the production and societal contexts of communication. Second:

CCO scholarship should be as inclusive as possible about what we mean by (organizational) communication. Although we tend to naturally acknowledge that messages, as components of communication processes, take on all kinds of form (kinesthetic, facial, textual, intonational, clothes, body shape, architectural, etc.), it remains that the vast majority of the work on organizational communication and discourse tends to focus almost exclusively on the textual aspects of communication. (Cooren et al., 2011)

This premise pinpoints the relevance of looking beyond the text dimension, and simultaneously examining the production and societal dimensions of communication. Third:

CCO scholarship acknowledges the co-constructed or co-oriented nature of (organizational) communication. If focusing on the performative character of (organizational) communication appears crucial to explore its constitutive nature, one should not neglect that any performance is as much the product of the agent that/who is deemed performing it as the product of the people who attend and interpret/respond to such performance-analysts included (Ashcraft et al., 2009; Taylor \& Van Every, 2000). (Cooren et al., 2011, p. 1152)

This premise stresses the relevance of investigating both the production and reception dimensions, and their interactions.

Bearing the lack of research on the production and reception dimensions, and their interactions with the text dimension of refugee organizations' public communication in mind, the adoption of the holistic CCO perspective thus seems very valuable: "partly because it opens up for new metatheoretical approaches, and partly because it invites one to a broadened view of what kinds of actors and communication activities could be perceived as essential to organizational strategic communication" (Heide et al., 2018, p. 455). Given the rather general nature of strategic communication, we discuss the relevance of the more specific, related and partially overlapping fields of non-profit and public communication for examining and defining refugee organizations' public communication.

\subsection{Non-Profit Communication}

As the visibility and (societal) relevance of non-profit communication recently have grown, scholarly interest in this subfield of strategic communication has increased (Oliveira, Melo, \& Gonçalves, 2016). Non-profit commu- nication is mainly (but not exclusively) performed by the civil society, which refers to "the organized expression of the values and interests of society" (Castells, 2008, p. 78). This form of communication is often considered as a facilitator of social transformation and progress, as it creates awareness around international social, political, economic and environmental issues, expresses particular world visions, shapes collective identities and affects corporate practices and government policies (Lewis, 2003; Wilkins, Tufte, \& Obregon, 2014). According to Oliveira et al. (2016) it provides an alternative and practical response to problems where both the corporate and the institutional structures are absent or have failed, which is arguably the case in the recent so-called 'refugee crises'. Central to non-profit communication is "humanity and the relations with the fields of life in the public sphere, not mediated directly or subscribed on the first instance to the logics of an institutionalised organisation" (Oliveira et al., 2016, p. 2).

NGOs play a key role in various societies worldwide, strongly supported by their communication practices (Schwarz \& Fritsch, 2015). Up to now, however, strategic communication used by NGOs has not received much attention in scientific research (Lewis, 2005; Tkalac \& Pavicic, 2009). Furthermore, most studies in the field of non-profit communication have adopted a businessand profit-driven logic to develop (positivist) theories, models and case studies, largely ignoring non-profit organizations' (NPOs) social values and goals (Oliveira et al., 2016). Moreover, only few scholars have investigated non-profit communication practices' discursive and rhetorical nature (Dempsey, 2012; Lewis, 2005).

Research informed by new approaches on NPOs' public communication and adopting a multi-perspective view, for example the CCO perspective, on refugee organizations' communication, roles, operations, values, goals and strategies is thus needed. As better communication strategies facilitate appropriate conditions for social change (Melo, Balonas, Ruão, \& Felício, 2016), a revision of the existing literature on refugee organizations' public communication is highly necessary. Oliveira's (2017, p. 59) definition of NGO strategic communication could guide this research, as it attempts to meet "the call for a turn towards a unified or holistic approach to communication within organizational settings, embedded in a social context of postmodernity as defined by Giddens (1991, 1997)." He considers it as: "the practice of symbolic social action (communication) to reach set goals, create the organization, perform civic relations and fulfil its mission by groups of people that pursue the common good for the interests of non-members" (Oliveira, 2017, p. 59).

\subsection{Public Communication}

While we recognize, in line with the CCO perspective, that the traditional borders between external and internal communication are fading (Cheney, Christensen, \& 
Dailey, 2014), this article focuses, however, for purposes of feasibility, only on external (public) communication. Likewise, this article recognizes that organizational communication is not only performed by communication professionals, but also by the organization's other employees. However, as communication professionals have considerably more expertise in and produce more public communication (Zerfass \& Huck, 2007), the article discusses their communication practices.

Public communication can be defined as a largescale, often diversified communication genre that consists of both informational and persuasive messages which are strategically directed towards various audiences in the public sphere through an organized and systematic framework of communication activities, channels and interpersonal networks to meet some objectives (Atkin \& Rice, 2013; Macnamara, 2016). It occurs both in regular day-to-day communication as well as in campaigns held in specific periods. Target audiences and/or stakeholders include (inter)national governments and bodies, other relevant organizations, private sector organizations, media and/or citizens (Green, 2018; Lang, 2012).

Further, public communication is predominantly 'public' in nature. First, it usually proceeds through publications, photos, videos and other content forms disseminated through traditional mass media, interpersonal networks, public events and, increasingly, websites and social media (Atkin \& Rice, 2013; Macnamara, 2016). Secondly, it occurs in the public sphere rather than in the private sphere and is about public themes rather than private affairs, such as refugee protection (Habermas, 1989). As such, we can differentiate communication campaigns from lobbying (Green, 2018). Generally speaking, NPOs use public communication to gain broader visibility, inform, sensitize, influence behaviours and set the agenda (Atkin \& Rice, 2013; Lang, 2012). The final goal is to obtain public, political, financial and/or practical support (Dijkzeul \& Moke, 2005).

\subsection{Refugee Organizations' Public Communication}

Integrating the above-mentioned insights on strategic, non-profit and public communication and adapting them to the subject, we propose a definition for refugee organizations' public communication. Important to mention is that we do not consider the following definition as complete and immutable, especially since the subject has hardly been examined, but as a starting point and guidance for future studies.

Strongly influenced by the understandings of Oliveira (2017), Atkin and Rice (2013), and Macnamara (2016), we consider refugee organizations' public communication as the practice of organized and systematic symbolic social action (diversified communication disseminated through a variety of channels and activities) within the public sphere to reach set goals, co-create the refugee organization, perform civic relations and fulfil its mission by groups of people that pursue the (perceived) common good for forced migration.

\section{Discussion and Conclusion}

This conceptual article discussed refugee organizations' public communication, focusing on its social and scientific relevance, state of the art, and position and opportunities for new perspectives within broader literature, and based on these findings also proposed a definition.

Following the discussed definitions, refugee organizations' public communication can be considered as a particular type of strategic communication. Strategic communication, however, is also a unifying framework which is, especially given the current (postmodern) context and (limited and rather positivist) state of art, highly relevant to examine communication processes (Falkheimer \& Heide, 2018; Holtzhausen \& Zerfass, 2015). Not surprisingly, little interpretative and discursive research has been conducted on strategic and non-profit communication (Dempsey, 2012; Lewis, 2005).

However, this article demonstrated that research on refugee organizations' public communication is both highly socially and scientifically relevant. More concretely, effective public communication strategies have become crucial for refugee organizations' operations to attract and influence media attention in response to the increased humanitarian needs (UNHCR, 2017), the growing humanitarian competitiveness (Cottle \& Nolan, 2007), and the rather and/or more negative public image of refugees (Lucassen, 2018).

To our knowledge, this is the first academic article which discusses the state of the art of refugee organizations' public communication and defines and situates it within broader fields of research. However, the article also revealed that current research mostly investigates the text dimension, but much less or rather indirectly (cf. research on humanitarian organizations in general) the production and reception dimensions. Future research should examine these dimensions and their interactions more in-depth and can benefit by adopting the holistic CCO perspective in order to meet the need of bridging normative and organizational views (Orgad, 2018). Multi-methodological, comparative, and interdisciplinary approaches should be taken into account, given the above-mentioned valuable insights from and interconnectedness between disciplines such as communication sciences, sociology, history, linguistics, (social) anthropology, (international) political sciences and international relations and diplomacy.

\section{Acknowledgments}

The author thanks all the peer reviewers for their relevant and useful feedback on earlier versions of this article. Further, the author also thanks his supervisor, Prof. Dr. Stijn Joye (Ghent University), for his helpful and constructive comments. Last but not least, the au- 
thor thanks Robert Hensley-King who adequately edited the draft version of this manuscript, and the Research Foundation-Flanders (FWO) which funds the author's $\mathrm{PhD}$ research project.

\section{Conflict of Interests}

The author declares no conflict of interests.

\section{References}

Altheide, D. L. (2004). Media logic and political communication. Political Communication, 21(3), 293-296.

Altheide, D. L., \& Snow, R. P. (1979). Media logic. Thousand Oaks, CA: Sage Publications.

Andersson, R. (2017). Rescued and caught: The humanitarian-security nexus at Europe's frontiers. In N. De Genova (Ed.), The borders of 'Europe': Autonomy of migration, tactics of bordering (pp. 64-94). London: Duke University Press.

Andersson, R. (2018). Migration. In T. Allen, A. Macdonald, \& H. Radice (Eds.), Humanitarianism. A dictionary of concepts (pp. 239-252). Abingdon: Routledge.

Atkin, C. K., \& Rice, R. E. (2013). Theory and principles of public communication campaigns. In R. E. Rice \& C. K. Atkin (Eds.), Public communication campaigns (4th ed., pp. 3-20). Los Angeles, CA: Sage.

Benson, R. (2013). Shaping immigration news: A FrenchAmerican comparison. New York, NY: Cambridge University Press.

Bettini, G. (2013). Climate barbarians at the gate? A critique of apocalyptic narratives on 'climate refugees'. Geoforum, 45(1), 63-72.

Betts, A. (2009). Protection by persuasion: International cooperation in the refugee regime. Ithaca, NY: Cornell University Press.

Betts, A. (2010). The refugee regime complex. Refugee Survey Quarterly, 29(1), 12-37.

Betts, A., Loescher, G., \& Milner, J. (2012). The United Nations High Commissioner for Refugees (UNHCR): The politics and practice of refugee protection into the 21st century (2nd ed.). London: Routledge.

Boomgaarden, H. G., \& Vliegenthart, R. (2009). How news content influences anti-immigration attitudes: Germany, 1993-2005. European Journal of Political Research, 48(4), 516-542.

Carragee, K. M., \& Roefs, W. (2004). The neglect of power in recent framing research. Journal of Communication, 54(2), 214-233.

Castells, M. (2008). The new public sphere: Global civil society, communication networks, and global governance. The ANNALS of the American Academy of Political and Social Science, 616(1), 78-93.

Cheney, G., Christensen, L. T., \& Dailey, S. (2014). Communicating identity and identification in and around organizations. In L. L. Putnam \& D. K. Mumby (Eds.), The SAGE handbook of organizational communica- tion: Advances in theory, research, and methods (3rd ed., pp. 695-716). Thousand Oaks, CA: Sage Publications.

Chouliaraki, L. (2012). Between pity and irony: Paradigms of refugee representation in humanitarian discourse. In K. Moore, B. Gross, \& T. Threadgold (Eds.), Migrations and the media (pp. 13-32). New York, NY: Peter Lang.

Chouliaraki, L., \& Zaborowski, R. (2017). Voice and community in the 2015 refugee crisis: A content analysis of news coverage in eight European countries. International Communication Gazette, 79(6/7), 613-635.

Cohen, S. (2001). States of denial: Knowing about atrocities and suffering. Cambridge: Polity Press.

Cooren, F., Kuhn, T., Cornelissen, J. P., \& Clark, T. (2011). Communication, organizing and organization: An overview and introduction to the special issue. Organization Studies, 32(9), 1149-1170.

Cottle, S., \& Nolan, D. (2007). Global humanitarianism and the changing aid-media field. Journalism Studies, $8(6), 862-878$.

Dempsey, S. E. (2012). Nonprofits as political actors. Management Communication Quarterly, 26(1), 147-151.

Dempster, H., \& Hargrave, K. (2017). Understanding public attitudes towards refugees and migrants (Working Paper, No. 512). London: Overseas Development Institute.

Dijkzeul, D., \& Moke, M. (2005). Public communication strategies of international humanitarian organizations. International Review of the Red Cross, 87(860), 673-691.

Dimitrov, R. (2006). Poor resources, rich communication: Public relation strategies by four refugee advocacy organisations in Australia. Paper presented at the Australia and New Zealand Third Sector Research, Eighth Biennial Conference, Navigating New Waters, Adelaide, Australia.

Dimitrov, R. (2009). New communication strategies? Lessons from the refugee rights movement in Australia. Paper presented at the Second Annual Conference of the Association for Non-profit and Social Economy Research (ANSER), Ottawa, Canada.

Entman, R. M. (1993). Framing: Toward clarification of a fractured paradigm. Journal of Communication, 43(4), 51-58.

European Commission. (2018). Special Eurobarometer 469: Integration of immigrants in the European Union (Report No. 2018.1682). Brussels: European Commission.

Fairclough, N., \& Wodak, R. (1997). Critical discourse analysis. In T. A. van Dijk (Ed.), Discourse as social interaction (pp. 258-284). London: Sage.

Falkheimer, J., \& Heide, M. (2018). Strategic communication: An introduction. London: Routledge.

Franks, S. (2013). Reporting disasters: Famine, aid, politics and the media. London: Hurst \& Co.

Frelick, B. (2007). Paradigm shifts in the international re- 
sponses to refugees. In J. D. White \& A. J. Marsella (Eds.), Fear of persecution: Global human rights, international law, and human well-being (pp. 33-57). Plymouth: Lexington Books.

Green, D. (2018). Advocacy. In T. Allen, A. Macdonald, \& H. Radice (Eds.), Humanitarianism: A dictionary of concepts (pp. 16-29). Abingdon: Routledge.

Habermas, J. (1989). The structural transformation of the public sphere. Cambridge: Polity Press.

Hallahan, K., Holtzhausen, D., Van Ruler, B., Verčič, D., \& Sriramesh, K. (2007). Defining strategic communication. International Journal of Strategic communication, 1(1), 3-35.

Harrell-Bond, B., \& Voutira, E. (1992). Anthropology and the study of refugees. Anthropology Today, 8(4), 6-10.

Harrell-Bond, B., \& Voutira, E. (2007). In search of 'invisible' actors: Barriers to access in refugee research. Journal of Refugee Studies, 20(2), 281-298.

Heide, M., Simonsson, C., von Platen, S., \& Falkheimer, J. (2017). Expanding the scope of strategic communication: Going beyond communication professionals and small-scale studies. Paper presented at the ICA Preconference Future Directions of Strategic Communication: Towards the Second Decade of an Emerging Field, San Diego, CA, USA.

Heide, M., von Platen, S., Simonsson, C., \& Falkheimer, J. (2018). Expanding the scope of strategic communication: Towards a holistic understanding of organizational complexity. International Journal of Strategic Communication, 12(4), 452-468.

Hellman, M., \& Lerkkanen, T. (2019). Construing oppositions, demarcating a we-ness: The dramaturgy of a live TV debate on the refugee crisis. European Journal of Cultural Studies, 22(1), 37-59.

Höijer, B. (2004). The discourse of global compassion: The audience and media reporting of human suffering. Media, Culture \& Society, 26(4), 513-531.

Holtzhausen, D., \& Zerfass, A. (2013). Strategic communication: Pillars and perspectives of an alternative paradigm. In K. Sriramesh, A. Zerfass, \& J.-N. Kim (Eds.), Public relations and communication management: Current trends and emerging topics (pp. 283-302). New York, NY: Routledge.

Holtzhausen, D., \& Zerfass, A. (2015). Strategic communication: Opportunities and challenges of the research area. In D. Holtzhausen \& A. Zerfass (Eds.), The Routledge handbook of strategic communication (pp. 3-17). New York, NY: Routledge.

Ihlen, $\varnothing$. (2007). Building on Bourdieu: A sociological grasp of public relations. Public Relations Review, 33(3), 269-274.

Lang, S. (2012). NGOs, civil society, and the public sphere. Cambridge: Cambridge University Press.

Leudar, I., Hayes, J., Nekvapil, J., \& Turner Baker, J. (2008). Hostility themes in media, community and refugee narratives. Discourse \& Society, 19(2), 187-221.

Lewis, D. (2003). Theorizing the organization and man- agement of non-governmental development organizations: Towards a composite approach. Public Management Review, 5(3), 325-344.

Lewis, L. (2005). The civil society sector: A review of critical issues and research agenda for organizational communication scholars. Management Communication Quarterly, 19(2), 238-267.

Lucassen, L. (2018). Peeling an onion: The "refugee crisis" from a historical perspective. Ethnic and Racial Studies, 41(3), 383-410.

Macnamara, J. (2016). Organisational listening. The missing essential in public communication. New York, NY: Peter Lang Publishing.

Malkki, L. H. (1996). Speechless emissaries: Refugees, humanitarianism, and dehistoricization. Cultural Anthropology, 11(3), 377-404.

McCombs, M. E., \& Shaw, D. L. (1972). The agendasetting function of mass media. Public Opinion Quarterly, 36(2), 176-187.

McCombs, M. E. (2014). Setting the agenda: Mass media and public opinion. Cambridge: Polity Press.

McQuail, D. (2010). McQuail's mass communication theory (6th ed.). New York, NY: Sage.

Melo, A. D., Balonas, S., Ruão, T., \& Felício, M. (2016). Strategic communication for public health: A research-action empowerment program. In E. Oliveira, A. D. Melo, \& G. Gonçalves (Eds.), Strategic communication for non-profit organisations (pp. 55-76). Wilmington, DE: Vernon Press.

Mumby, D. K. (2014). Critical theory and postmodernism. In L. L. Putnam \& D. K. Mumby (Eds.), The SAGE handbook of organizational communication: Advances in theory, research, and methods (pp. 101-126). London: Sage.

Musarò, P. (2017). Mare Nostrum: The visual politics of a military-humanitarian operation in the Mediterranean Sea. Media, Culture \& Society, 39(1), 11-28.

Newman, B. J., Hartman, T. K., Lown, P. L., \& Feldman, S. (2015). Easing the heavy hand: Humanitarian concern, empathy, and opinion on immigration. British Journal of Political Science, 45(3), 583-607.

Nikunen, K. (2016). Media, passion and humanitarian reality television. European Journal of Cultural Studies, 19(3), 265-282.

Office of the United Nations High Commissioner for Refugees. (2010). Statute of the Office of the United Nations High Commissioner for Refugees. Geneva: UNHCR.

Office of the United Nations High Commissioner for Refugees. (2017). Global appeal 2018-2019. Geneva: UNHCR. Office of the United Nations High Commissioner for Refugees. (2018). Global trends: Forced displacement in 2017. Geneva: UNHCR.

Oliveira, E. (2017). The instigatory theory of NGO communication (ITNC) (Doctoral dissertation). Universidade do Minho, Minho, Portugal.

Oliveira, E., Melo, A. D., \& Gonçalves, G. (2016). Strategic communication for non-profit organisations. Wilm- 
ington, DE: Vernon Press.

O'Neil, G. (2013). Evaluation of international and nongovernmental organizations' communication activities: A 15-year systematic review. Public Relations Review, 39(5), 572-574.

Ongenaert, D., \& Joye, S. (2016). Who needs help? A critically informed qualitative content analysis of western news media representations of aid agencies in the aftermath of typhoon Haiyan (2013). Tijdschrift voor Communicatiewetenschap, 44(3), 272-287.

Ongenaert, D., \& Joye, S. (2019). Selling displaced people? A multi-method study of international refugee organizations' public communication strategies towards the Syrian displacement crisis. Disasters, 43(3). https://doi.org/10.1111/disa.12353

Orgad, S. (2018). Communication. In T. Allen, A. Macdonald, \& H. Radice (Eds.), Humanitarianism. A dictionary of concepts (pp. 68-80). Abingdon: Routledge.

Pupavac, V. (2008). Refugee advocacy, traumatic representations and political disenchantment. Government and Opposition, 43(2), 270-292.

Putnam, L., \& Nicotera, A. M. (2010). Communicative constitution of organization is a question: Critical issues for addressing it. Management Communication Quarterly, 24(1), 158-165.

Rajaram, P. K. (2002). Humanitarianism and representations of the refugee. Journal of Refugee Studies, 15(3), 247-264.

Reich, Z. (2010). Measuring the impact of PR on published news in increasingly fragmented news environments: A multifaceted approach. Journalism Studies, 11(6), 799-816.

Reich, Z. (2011). Source credibility as a journalistic work tool. In B. Franklin \& M. Carlson (Eds.), Journalists, sources, and credibility: New perspectives (pp. 19-36). New York, NY: Routledge.

Rodriguez, N. S. (2016). Communicating global inequalities: How LGBTI asylum-specific NGOs use social media as public relations. Public Relations Review, 42(2), 322-332.

Sallot, L. M., \& Johnson, E. A. (2006). Investigating relationships between journalists and public relations practitioners: Working together to set, frame and build the public agenda, 1991-2004. Public Relations Review, 32(2), 151-159.

Schudson, M. (2011). The sociology of news (2nd ed.). New York, NY: W. W. Norton \& Company.

Schwarz, A., \& Fritsch, A. (2015). Strategic communication practice of international nongovernmental organizations. In D. Holtzhausen \& A. Zerfass (Eds.), The Routledge handbook of strategic communication (pp. 459-480). New York, NY: Routledge.
Seu, I. B., \& Orgad, S. (2017). Caring in crisis? Humanitarianism, the public and NGOs. Cham: Springer.

Sigona, N. (2018). The contested politics of naming in Europe's "refugee crisis". Ethnic and Racial Studies, 41(3), 456-460.

Tester, K. (2001). Compassion, morality and the media. Buckingham: Open University Press.

Tkalac, A., \& Pavicic, J. (2009). Nongovernmental organizations and international public relations. In K. Sriramesh \& D. Vercic (Eds.), The global public relations handbook: Theory, research, and practice. Revised and expanded edition (pp. 490-504). New York, NY: Routledge.

Van Leuven, S., Deprez, A., \& Raeymaeckers, K. (2013). Increased news access for international NGOs? How Médecins Sans Frontières' press releases built the agenda of Flemish newspapers (1995-2010). Journalism Practice, 7(4), 430-445.

Van Leuven, S., \& Joye, S. (2014). Civil society organizations at the gates? A gatekeeping study of news making efforts by NGOs and government institutions. The International Journal of Press/Politics, 19(2), 160-180.

Vasavada, K. D. (2016). Then and now: Evolving representations of children in UNICEF photographs. Intersect: The Stanford Journal of Science, Technology and Society, 9(3), 1-26.

Waisbord, S. (2011). Can NGOs change the news? International Journal of Communication, 5(24), 142-165.

Walker, P., \& Maxwell, D. (2009). Shaping the humanitarian world. New York, NY: Routledge.

Walters, W. (2011). Foucault and frontiers: Notes on the birth of the humanitarian border. In U. Bröckling, S. Krasmann, \& T. Lemke (Eds.), Governmentality: Current issues and future challenges (pp. 138-164). London: Routledge.

Waters, R. D., \& Tindall, N. T. (2011). Exploring the impact of American news coverage on crisis fundraising: Using media theory to explicate a new model of fundraising communication. Journal of Nonprofit \& Public Sector Marketing, 23(1), 20-40.

Wilkins, K. G., Tufte, T., \& Obregon, R. (2014). The handbook of development communication and social change. London: Wiley-Blackwell.

Wolfsfeld, G. (2011). Making sense of media and politics: Five principles in political communication. New York, NY: Routledge.

Zerfass, A., \& Huck, S. (2007). Innovation, communication, and leadership: New developments in strategic communication. International Journal of Strategic Communication, 1(2), 107-112. 


\section{About the Author}

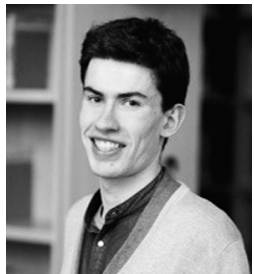

David Ongenaert, in 2017, started as a FWO PhD Fellow under supervision of Prof. Dr. Stijn Joye at Ghent University's Department of Communication Sciences. He is a member of the Centre for Cinema and Media Studies (CIMS), the Center for Journalism Studies (CJS), the Center for Persuasive Communication (CEPEC) and the Centre for the Social Study of Migration and Refugees (CESSMIR). He investigates international refugee organizations' public communication strategies towards displacement crises by exploring its text, production and audience dimensions. 